\title{
Quality characteristics of 'Kochujang' made with pigmented rice flour 'Nuruk' by various fungal strains during aging
}

\author{
Hee-Won Lee ${ }^{1}$, Hong-Bi Han ${ }^{1}$, Bok-seon $\mathrm{Kim}^{1}$, Cheol-Min Kim ${ }^{1}$, Hyo-Gyeong Woo ${ }^{1}$, \\ Jae-Hee Jeong ${ }^{1}$, So-Mang Kim ${ }^{1,2}$, Chang-Ki Huh ${ }^{1,2 *}$ \\ ${ }^{1}$ Department of Food Science and Technology, Sunchon National University, Suncheon 57922, Korea \\ ${ }^{2}$ Research Institute of Food Industry, Sunchon National University, Suncheon 57922, Korea
}

\section{곰팡이 균주별 유색미 쌀가루 개량누룩을 첨가한 고추장의 숙성 중 품질 특성

$$
\begin{gathered}
\text { 이희원 }{ }^{1} \cdot \text { 한홍비 }^{1} \cdot \text { 김복선 }^{1} \cdot \text { 김철민 }^{1} \cdot \text { 우효경 }^{1} \cdot \text { 정재희 }^{1} \cdot \text { 김소망 }^{1,2} \cdot \text { 허창기 }^{1,2 *} \\
{ }^{1} \text { 순천대학교 식품공학과, }{ }^{2} \text { 순천대학교 식품산업연구소 }
\end{gathered}
$$

\begin{abstract}
In this study, pigmented rice flour 'Nuruk' was prepared using various fungal strains to improve the quality of Korean traditional 'Kochujang', and the quality characteristics during the aging of 'Kochujang' made with the 'Nuruk' were confirmed. The $\mathrm{pH}$ of 'Nuruk' was highest using Aspergillus oryzae pigmented rice flour 'Nuruk' (N2) at 5.83, and the highest acidity was Aspergillus niger pigmented rice flour 'Nuruk' (N3) at 2.69. The crude ash content was $1.10-1.14 \%$ from the 'Nuruk' made with pigmented rice flour, which was higher than the $0.42 \%$ from 'Nuruk' made with white rice flour. The $\mathrm{pH}$ of 'Kochujang' decreased gradually from $\mathbf{0}$ to 90 days as aging progressed. The titratable acidity was $\mathbf{2 . 7 6 - 3 . 7 1 \%}$, which increased with increasing aging period. During the aging of 'Kochujang', the water content increased by $2-3 \%$. The reducing sugar content decreased from 0.33 to $3.25 \%$ after 60 days of aging and increased to 3.85 to $4.94 \%$ at the end of aging. Regarding the color values, the 'Kochujang' made with white rice flour 'Nuruk' showed higher overall $L$, $a$, and $b$ values than the 'Kochujang' made with pigmented rice flour 'Nuruk'. A sensory evaluation of six kinds of 'Kochujang' revealed the 'Kochujang' made with N2 'Nuruk' to have the highest preference in all evaluation items.
\end{abstract}

Key words : pigmented rice flour, Nuruk, Kochujang, quality, aging

서 론

현재 우리나라 식문화는 다양한 사회적 변화를 통해 1 인 주거형태 및 맞벌이 가정이 늘어나 편리성, 간편성을 추구하 는 형태로 변화되고 있고, 삶의 질이 높아지면서 가정식에 대 한 그리움과 전통을 추구하는 경향 또한 높아져 전통 식품에 대한 요구가 많아졌다(Kim과 Byun, 2017).

고추장은 원료의 배합 비율이나 담금 방법 및 지역에 따라
다양한 제조방법으로 제조하고 있고, 다른 장류와 함께 오늘 날 우리나라 식문화에서 빠질 수 없는 전통 식품이다(Park 등, 2016a). 고추장은 자극적이진 않지만 중독성 있는 매운맛 으로 가공식품에 많이 이용되며(Jin 등, 2007), 고추장의 향 미와 맛은 단순히 원료로 결정되지 않고 숙성 중에 미생물 대사가 작용되어 형성하는 물질과 탄수화물의 가수분해에 의 한 단맛, 콩 단백질 아미노산의 감칠맛, 고추의 매운맛, 소금 의 짠맛이 조화에 의해 맛과 향, 품질이 영향을 받는다(Lee와

*Corresponding author. E-mail : hck1008@sunchon.ac.kr, Phone : +82-61-750-3251, Fax : +82-61-750-3250

Received 03 August 2020; Revised 07 September 2020; Accepted 08 September 2020.

Copyright (c) The Korean Society of Food Preservation.

This is an Open Access article distributed under the terms of the Creative Commons Attribution Non-Commercial License (http://creativecommons.org/licenses/by-nc/4.0) which permits unrestricted non-commercial use, distribution, and reproduction in any medium, provided the original work is properly cited. 
Lee, 2006; Jin 등, 2007). 이는 미생물 작용이 원료의 대사 작용에 맛을 기여하는 정도가 매우 중요함을 나타낸다 $(\mathrm{Oh}$ 등, 2013). 전통식 고추장 제조 방식으로는 주로 엿기름과 메 줏가루, 고춧가루 등을 혼합하여 숙성시켜 제조하며, 전분질 원료로는 찹쌀이 주로 사용되나 밀가루, 보리, 고구마 등이 이용되기도 한다(Lee와 Lee, 2006). 기존 고추장에 관한 연구 로는 주로 고추장의 저장성 향상과 전분질의 종류와 배합을 달리하여 품질을 개선하기 위한 연구들이 주를 이루었다 (Park 등, 2016a). 최근에는 건강적 측면에서 기능성 소재를 첨가하여 생리 기능성이 보다 강화된 고추장 제조에 관한 연 구가 진행되고 있다(Cha 등, 2011; Lee 등, 2019). 지금까지 의 고추장 관련 연구를 보면 본 연구에서 수행하고자 하는 누룩을 활용해 제조되는 고추장 관련된 연구는 거의 이루어 지지 않고 있는 실정이다.

쌀은 과거로부터 중요한 식량 자원이었으나, 현재는 다양 한 문화의 교류로 인해 식문화가 점차 바뀌면서 소비량이 지 속적으로 줄어들어 쌀을 이용한 가공성의 다양화 및 기능성 을 고려하여 특수미의 개발이 이루어지고 있다(Park 등, 2002). 그 중 유색미는 면역력 향상과 건강에 대한 선호도가 높아지면서 주식인 쌀 중에서도 유색미의 소비가 늘어나고 있다. 유색미는 일반적으로 안토시아닌이 풍부하고 cyanidin 3-O-glucoside(C3G)의 함량이 높다고 보고되고 있고(Park 등, 2012), 이외에 보통 백미 품종보다 단백질, 비타민, 미네 랄 등 영양적 가치가 월등히 높을 뿐만 아니라, 미강층 추출 물의 항산화 활성이 우수하며, 질병 예방 및 노화 방지 효과 가 인정되어 건강 기능성 측면에서 높은 식품 가치로 평가되 고 있다(Park 등, 2016b). 또한, 유색미는 다양한 색깔을 띄고 있으며, 그 중 적색을 띄는 유색미가 가장 높은 비율을 차지 한다. 적색을 띄는 유색미의 경우 다양한 가공 식품에 원료와 부원료로 사용이 가능하며, 본 연구에서 진행하고자 하는 고 추장은 대표적으로 붉은색을 띄는 식품으로써 고추장의 품질 향상과 기능성 향상에 유색미는 적합한 소재라 판단되었다.

따라서 본 연구에서는 우리나라 전통 고추장의 품질 향상 의 일환으로 유색미를 활용하고자 곰팡이 균주별로 유색미 누룩을 제조하여 품질을 평가하고, 제조된 곰팡이 균주별 유 색미 누룩을 첨가한 고추장을 제조하여 숙성 중에 일어나는 다양한 품질 특성을 조사하였다.

\section{재료 및 방법}

\section{실험 재료}

본 실험에 사용한 누룩 제조용 백미는 전라남도 광양시에 위치한 (주)광양주조공사에서 확보한 2017년산 한아름쌀 품종 이고, 유색미는 전라남도 식량작물연구소(Naju, Korea)에서
육성하여 품종 등록(품종보호권 등록번호 제7257호)한 다향 흑미(2018년산)를 실온에서 보관하면서 사용하였다. 조제종국 은 시중에 판매 중인 황국(황국조제종국, YES WINE, Boeun, Korea), 흑국(흑국조제종국, YES WINE, Boeun, Korea), 백 국(백국조제종국, Chungmoo Fermentation, Ulsan, Korea), Penicillium candidum(SWUNG FD PCA-3(10U), Chr. Hansen SA, France) 균주 등 4종의 곰팡이 균주를 확보해 사 용하였으며, 고추장 제조용 고춧가루(Geumsong Powder Village, Chilgok, Korea), 엿기름가루(Jeonwonfood, Gimpo, Korea), 메줏가루(Isaac's Garden, Namyangju, Korea), 천일 염(Chungjungone, Shinan, Korea), 찹쌀가루(Samjinfoods, Soengju, Korea)를 확보하여 사용하였다. 본 실험에 사용된 분석 및 용매와 시약(Sigma-Aldrich Co., St. Louis, MO, USA)은 일급 또는 특급시약을 구입하여 사용하였다.

\section{누룩 제조}

쌀가루 개량누룩 제조는 Lee 등(2019)의 방법에 따라 쌀을 분쇄한 쌀가루에 $100^{\circ} \mathrm{C}$ 의 온수 $30 \%$ 를 가하여 익반죽한 뒤, 반죽의 온도가 $30^{\circ} \mathrm{C}$ 에 도달했을 때 4종의 곰팡이 조제종국을 각각 $0.3 \%$ 씩 첨가해 2 차 혼합하였다. 반죽 후 성형틀에 넣고 성형하여 누룩 상자에 넣고 $30^{\circ} \mathrm{C}$, 습도 $85 \%$ 에서 48 시간 동 안 1차 배양하였다. 2 차 배양은 누룩 상자의 뚜껑을 제거하고 $25^{\circ} \mathrm{C}$, 습도 $85 \%$ 에서 누룩을 상자에 기대어 7 일간 배양 후 수분함량이 $10 \%$ 내외가 되게 건조하여 제조하였다(Fig. $1 \mathrm{~A})$.

\section{고추장 제조}

곰팡이 균주별 쌀가루 개량누룩 첨가 고추장의 제조는 엿 기름가루 $40 \mathrm{~g}$ 를 정제수 $600 \mathrm{~mL}$ 에 3시간 침지시키고, 면 보 자기를 이용하여 여과시킨 후 가열하고 찹쌀가루 $200 \mathrm{~g}$ 을 가 열한 엿기름 물에 혼합하여 찹쌀죽을 만든 뒤 소금 $100 \mathrm{~g}$, 메줏가루 $150 \mathrm{~g}$, 고춧가루 $200 \mathrm{~g}$, 곰팡이 균주별 쌀가루 개량 누룩 $150 \mathrm{~g}$ 을 넣어 혼합하고, $25^{\circ} \mathrm{C}$ 에서 90 일간 밀봉하여 숙 성시켰다. 4종의 유색미 쌀가루 개량누룩을 혼합하여 첨가한 고추장 제조는 4종의 곰팡이 균주별로 제조된 각각의 쌀가루 개량누룩 $37.5 \mathrm{~g}$ 씩을 $150 \mathrm{~g}$ 이 되도록 혼합하고, Table 1에서 보는 바와 같이 고추장 제조의 레시피에 첨가하여 $25^{\circ} \mathrm{C}$ 에서 90일간 밀봉하여 숙성시켰다(Fig. 1B). 제조된 누룩과 고추 장의 사진은 Fig. 2에서 보는 바와 같다.

\section{$\mathrm{pH}$, 산도 및 환원당 측정}

$\mathrm{pH}$ 는 누룩과 숙성 중인 고추장 $1 \mathrm{~g}$ 에 증류수 $9 \mathrm{~mL}$ 를 가 한 후 혼합하여 $\mathrm{pH}$ meter(HM-40X, DKK-TOA, Tokyo, Japan)를 사용해 측정하였다. 산도 측정에서 누룩의 산도는 누룩 $20 \mathrm{~g}$ 에 물 $100 \mathrm{~mL}$ 를 가해 3 시간 이상 침출 후 여과하 


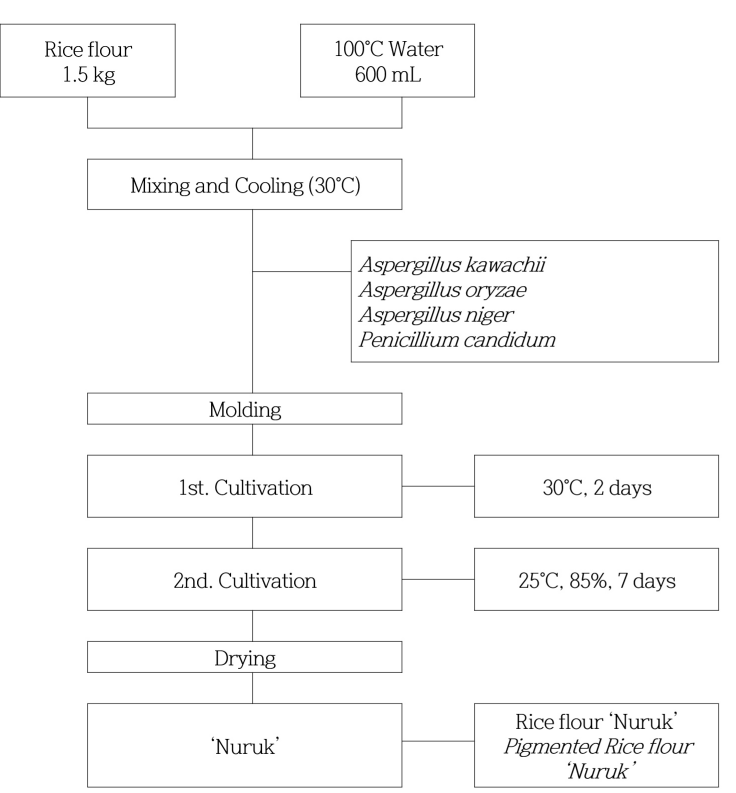

(A)

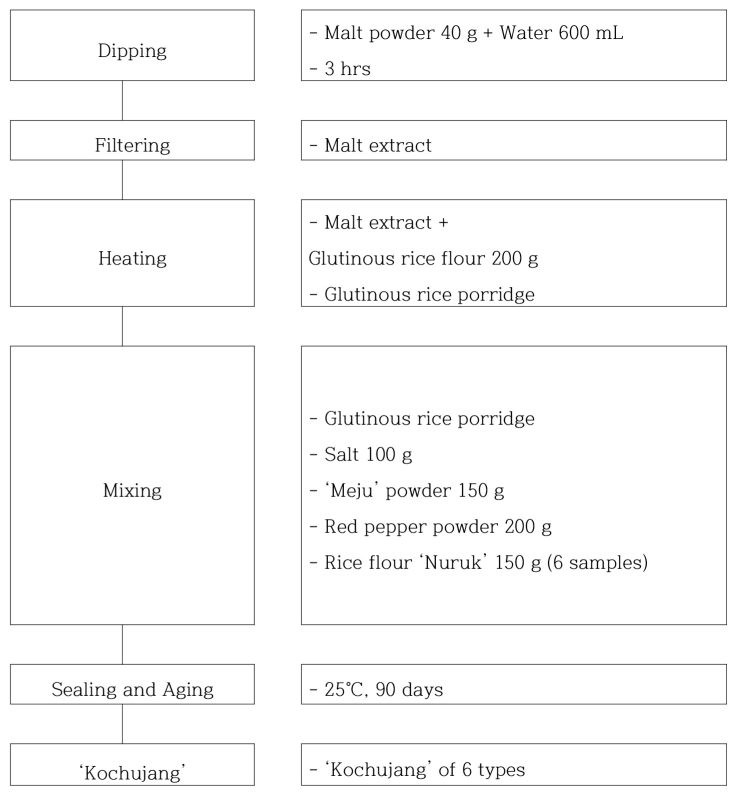

(B)

Fig. 1. Process for the preparation of rice flour 'Nuruk' by various fungal strains (A), process for the preparation of 'Kochujang' by pigmented rice flour 'Nuruk' (B).

Table 1. Mixing ratio of 'Kochujang' made with pigmented rice flour 'Nuruk'

(unit: g)

\begin{tabular}{|c|c|c|c|c|c|c|}
\hline Sample & $\mathrm{K} 1^{1)}$ & $\mathrm{K} 2$ & $\mathrm{~K} 3$ & K4 & K5 & K6 \\
\hline Malt powder & 40 & 40 & 40 & 40 & 40 & 40 \\
\hline Water & 600 & 600 & 600 & 600 & 600 & 600 \\
\hline Chili powder & 200 & 200 & 200 & 200 & 200 & 200 \\
\hline Glutinous rice powder & 200 & 200 & 200 & 200 & 200 & 200 \\
\hline Salt & 100 & 100 & 100 & 100 & 100 & 100 \\
\hline Meju powder & 150 & 150 & 150 & 150 & 150 & 150 \\
\hline $\mathrm{N} 1^{2)}$ & 150 & - & - & - & - & - \\
\hline $\mathrm{N} 2$ & - & 150 & - & - & - & 37.5 \\
\hline $\mathrm{N} 3$ & - & - & 150 & - & - & 37.5 \\
\hline N4 & - & - & - & 150 & - & 37.5 \\
\hline N5 & - & - & - & - & 150 & 37.5 \\
\hline
\end{tabular}

${ }^{1)} \mathrm{K} 1$, 'Kochujang' made with N1; K2, 'Kochujang' made with N2; K3, 'Kochujang' made with N3; K4, 'Kochujang' made with N4; K5, 'Kochujang' made with $\mathrm{N} 5$; K6, 'Kochujang' made with $\mathrm{N} 2+\mathrm{N} 3+\mathrm{N} 4+\mathrm{N} 5$.

${ }^{2} \mathrm{~N} 1$, whited rice flour 'Nuruk' made with $A$. oryzae; N2, pigmented rice flour 'Nuruk' made with $A$. oryzae; N3, pigmented rice flour 'Nuruk' made with $A$. kawachii; N4, pigmented rice flour 'Nuruk' made with A. niger; N5, pigmented rice flour 'Nuruk' made with $P$. candidum.

여 이 여액 $10 \mathrm{~mL}$ 에 혼합지시액 2-3 방울을 가하여 $0.1 \mathrm{~N}$ $\mathrm{NaOH}$ 용액으로 중화 적정시켰으며(Kwon 등, 2013), 고추 장의 적정 산도는 시료 $1 \mathrm{~mL}$ 에 증류수 $9 \mathrm{~mL}$ 를 가한 후 혼
합하여 희석시킨 뒤 $0.1 \mathrm{~N} \mathrm{NaOH}$ 용액으로 중화 적정시킨 후 0.009를 곱하여 lactic acid로 환산하였다(Huh, 2006). 고 추장의 환원당 함량 변화는 시료 $10 \mathrm{~mL}$ 를 Somogyi변법 
(A)

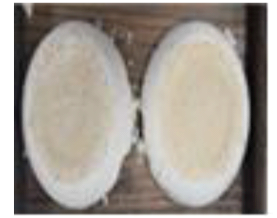

N1

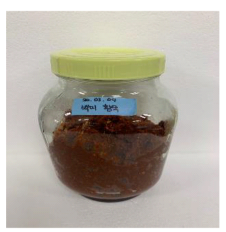

K1

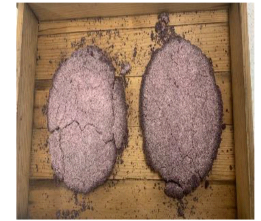

N2

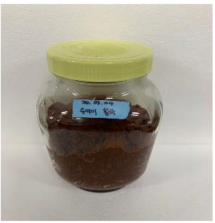

K2

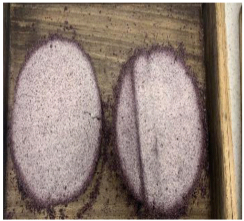

N3

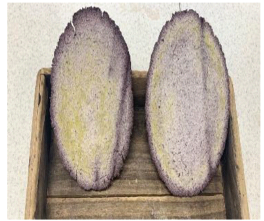

N4

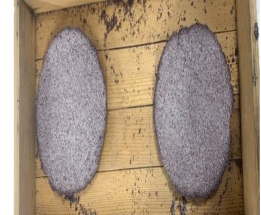

N5

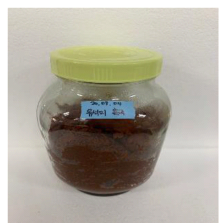

K3

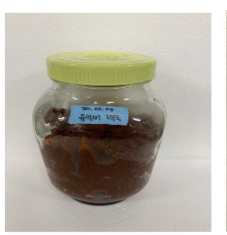

K4

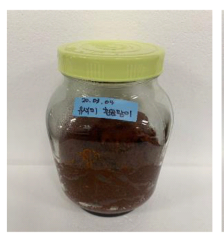

K5

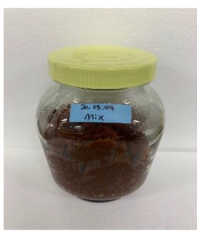

K6

Fig. 2. Photographs of rice flour 'Nuruk' (A) made with various fungal strains, and 'Kochujang' (B) made with pigmented rice flour 'Nuruk'. $\mathrm{N} 1$, whited rice flour 'Nuruk' made with $A$. oryzae; N2, pigmented rice flour 'Nuruk' made with $A$. oryzae; N3, pigmented rice flour 'Nuruk' made with $A$. kawachii; N4, pigmented rice flour 'Nuruk' made with A. niger; N5, pigmented rice flour 'Nuruk' made with $P$. candidum., K1, 'Kochujang' made with N1; K2, 'Kochujang' made with N2; K3, 'Kochujang' made with N3; K4, 'Kochujang' made with N4; K5, 'Kochujang' made with N5; K6, 'Kochujang' made with N2+N3+N4+N5.

(Hatakana와 Kobara, 1989)에 준하여 정량 후 glucose 함량 으로 표시하였다.

\section{일반성분 분석}

누룩과 고추장의 일반성분은 $\mathrm{AOAC}$ 법(2005)에 의하여 분 석하였다. 즉, 수분함량은 $105^{\circ} \mathrm{C}$ 에서 상압건조법, 회분 함량 은 $550^{\circ} \mathrm{C}$ 에서 직접 회화법을 이용하여 분석하였다. 조단백질 함량은 micro-Kjeldahl법을 이용하여 분석하였으며, 질소계 수 6.25 을 곱하여 계산하였다. 조지방 함량은 Soxhlet법을 이 용하여 분석하였다.

\section{식염 함량 측정}

식염은 $\mathrm{Oh}$ 등(2002)의 방법에 따라 각 시료별 $1 \mathrm{~g}$ 씩 무게를 측정하여 이를 증발시킨 후 회화시켜 증류수 $500 \mathrm{~mL}$ 로 mass up한 후 여액을 이용하여 $0.02 \mathrm{~N} \mathrm{AgNO}_{3}$ 으로 적정하였다.

\section{색도 측정}

시료 일정량 취해 색차계(Super color sp-80, Denshoku, Tokyo, Japan)를 이용해 $\mathrm{X}=80.84, \mathrm{Y}=82.22, \mathrm{Z}=92.98$ 인 표준 백색판(standard white plate)으로 보정하여 사용하였다. 측정 값은 $\mathrm{L}$ (lightness), a(redness), $\mathrm{b}$ (yellowness)값으로 측정하여 표시하였다.

\section{관능평가}

고추장의 관능평가는 10 명의 패널을 선정하여 향(flavor), 색(color), 단맛(sweetness), 짠맛(salty), 매운맛(spicy), 구수 한맛(delicate flavor), 전체적인 기호도(overall preference)를 9단계 평가법으로 실시하였다. 채점 기준은 아주 좋다; 9점, 보통이다; 5점, 아주 나쁘다; 1점으로 하였고, 관능평가는 순천대학교 생명윤리심의위원회 심의 결과 승인(1040173202006-HR-017-02)을 받은 후 시행되었다.

\section{통계처리}

본 실험은 독립적으로 3 회 이상 반복 실시하여 실험결과를 SPSS 통계분석 프로그램(25, IBM Corp., Armonk, NY, USA) 을 이용하였고, mean $\pm \mathrm{SD}$ 를 구하였으며, Duncan's multiple range test에 의해 평균치 간의 유의성을 검정하였다. 또한 독 립된 두 집단의 평균값 비교는 두 표본 t-검정(two sample t-test)을 이용하여 분석하였다.

\section{결과 및 고찰}

\section{개량누룩의 $\mathrm{pH}$ 및 산도}

일반적으로 누룩의 $\mathrm{pH}$ 와 산도는 발효물의 풍미나 산미에 영향을 주는 것으로 알려져 있다(Han 등, 1997). 본 연구에 서 제조할 고추장 또한 누룩의 $\mathrm{pH}$ 와 적정산도에 따라 품질 에 영향을 미칠 것으로 판단하여, 제조된 곰팡이 균주별 유 색미 쌀가루 개량누룩의 $\mathrm{pH}$ 와 산도를 측정한 결과는 Table 2 와 같다. $\mathrm{pH}$ 는 A. oryzae 균주를 첨가해 제조한 유색미 쌀 가루 개량누룩(N2 누룩)이 5.83으로 가장 높았고, A. niger 
균주를 첨가해 제조한 유색미 쌀가루 개량누룩(N4 누룩)은 4.15 로 누룩별 $\mathrm{pH}$ 차이가 크게 나타났다. 산도의 경우 $\mathrm{pH}$ 측 정 결과 값이 가장 낮게 나타난 N4 누룩이 산도 측정 결과 에서는 2.69로 가장 높게 나타났고, A. oryzae 균주를 첨가 해 제조한 백미 쌀가루 개량누룩(N1 누룩)이 1.60으로 가장 낮게 나타났다. 측정 결과를 살펴보면 N4 누룩의 경우 산성 을 띄고 있기 때문에 다른 누룩에 비해 고추장의 발효와 풍 미에 영향이 줄 것으로 판단된다. 백미를 이용해 제조한 누 룩과 유색미를 이용해 제조한 누룩의 $\mathrm{pH}$ 및 산도의 경우 $\mathrm{pH}$ 는 상관관계를 보이지 않았고, 산도는 백미를 이용해 제 조한 누룩이 유색미를 이용해 제조한 누룩에 비해 낮게 나 타났다.

\section{개량누룩의 일반성분}

누룩의 일반 성분 함량을 측정한 결과는 Table 3 과 같다. 본 연구에서의 누룩의 제조 방법을 보면 건조 과정을 거치게

Table 2. The $\mathrm{pH}$ and acidity of rice flour 'Nuruk' made with various fungal strains

\begin{tabular}{ccc}
\hline Sample $^{1)}$ & $\mathrm{pH}$ & Acidity \\
\hline $\mathrm{N} 1$ & $4.96 \pm 0.01^{2) \mathrm{c} 3)}$ & $1.60 \pm 0.07^{\mathrm{d}}$ \\
$\mathrm{N} 2$ & $5.83 \pm 0.01^{\mathrm{a}}$ & $2.14 \pm 0.05^{\mathrm{b}}$ \\
$\mathrm{N} 3$ & $4.37 \pm 0.01^{\mathrm{d}}$ & $2.13 \pm 0.02^{\mathrm{b}}$ \\
$\mathrm{N} 4$ & $4.15 \pm 0.01^{\mathrm{e}}$ & $2.69 \pm 0.01^{\mathrm{a}}$ \\
$\mathrm{N} 5$ & $5.15 \pm 0.01^{\mathrm{b}}$ & $1.81 \pm 0.02^{\mathrm{c}}$ \\
\hline
\end{tabular}

${ }^{1)} \mathrm{N} 1$, whited rice flour 'Nuruk' made with $A$. oryzae; N2, pigmented rice flour 'Nuruk' made with $A$. oryzae; $\mathrm{N} 3$, pigmented rice flour 'Nuruk' made with A. kawachii; N4, pigmented rice flour 'Nuruk' made with $A$. niger; N5, pigmented rice flour 'Nuruk' made with $P$. candidum.

${ }^{2)}$ All values are mean $\pm \mathrm{SD}$.

${ }^{3)}$ Values with different superscript letters in the same column are significantly different at $\mathrm{p}<0.05$ by Duncan's multiple range test $(\mathrm{a}>\mathrm{b}>\mathrm{c}>\mathrm{d}>\mathrm{e})$
되는데, 최종 제조할 누룩의 수분함량이 $10 \%$ 내외가 되도록 건조하는 목표를 설정하였다. 누룩의 수분함량은 저장성에 영향을 미치게 되는데, Lee 등(2009)은 누룩의 수분함량이 $14 \%$ 이상일 경우 저장성을 감소시키는 문제를 가져올 수 있 다고 보고하였다. 본 연구에서 제조된 누룩의 수분함량을 측 정한 결과, 모든 시료구에서 $14 \%$ 이하의 수분함량을 보여 저 장성이 확보된 것으로 확인되었다. 시료구별 수분함량의 차 이는 A. kawachii와 P. candidum 균주로 제조한 유색미 쌀가 루 개량누룩(N3 누룩과 N5 누룩)이 $12.35 \%$ 와 $12.25 \%$ 로 높 게 나타났고, N2 누룩이 $7.69 \%$ 로 가장 낮은 함량을 보였다. 조단백질 함량은 N3 누룩이 $9.31 \%$ 로 가장 높은 함량은 보였 으나, 다른 시료구와 큰 차이는 보이지 않았다. 조지방 함량은 $\mathrm{N} 2$ 누룩이 $1.44 \%$ 로 가장 높았고, N1 누룩은 $0.64 \%$ 로 가장 낮은 함량을 보였다. 조회분 함량은 쌀 품종에 따라 유의적 차 이를 보였다. 유색미를 이용해 제조한 누룩의 경우 $1.10-1.14 \%$ 의 조회분 함량을 보였고, 백미를 이용해 제조한 누룩의 경우 $0.42 \%$ 로 유색미를 이용해 제조한 누룩이 유의적으로 높게 나타났다. 이러한 차이는 Park 등(2002)이 보고한 유색미와 일반미(백미)의 조회분 함량을 비교한 결과, 유색미는 $1.53 \%$ 였고, 백미의 경우 $0.48 \%$ 였다고 보고해 원료인 쌀의 품종 차 이에 의해 제조된 누룩의 조회분 함량에도 영향을 미친 것으 로 판단된다.

\section{고추장의 $\mathrm{pH}$ 및 적정산도}

제조된 쌀가루 개량누룩을 이용해 6 종의 고추장을 제조하 고, 숙성 중의 $\mathrm{pH}$ 및 적정산도를 측정한 결과는 각각 Fig. 3,4 에서 보는 바와 같다. 시료구별 고추장의 $\mathrm{pH}$ 는 큰 차이를 보이지 않았고, 숙성 기간에 따른 $\mathrm{pH}$ 의 변화는 감소하는 경 향을 보였다. 숙성 중 6 종의 고추장 $\mathrm{pH}$ 는 담금 초기( 0 일 차) 에는 5.27-5.59였고, 숙성 30일 차에는 0.3-0.5가량 저하되었 으며, 숙성 90일째 pH는 4.60-4.85였다(Fig. 3). Lee 등(2014) 이 지역별로 제조된 고추장을 수집하여 $\mathrm{pH}$ 를 측정한 결과 평

Table 3. Proximate composition of rice flour 'Nuruk' made with various fungal strains

\begin{tabular}{ccccc}
\hline Sample $^{1)}$ & Moisture (\%) & Crude protein (\%) & Crude fat (\%) & Crude ash (\%) \\
\hline N1 & $10.70 \pm 0.32^{2 \mathrm{~b} 3)}$ & $8.99 \pm 0.30^{\mathrm{ab}}$ & $0.64 \pm 0.11^{\mathrm{c}}$ & $0.42 \pm 0.09^{\mathrm{b}}$ \\
N2 & $7.69 \pm 1.67^{\mathrm{c}}$ & $8.85 \pm 0.72^{\mathrm{ab}}$ & $1.44 \pm 0.06^{\mathrm{a}}$ & $1.43 \pm 0.25^{\mathrm{a}}$ \\
N3 & $12.35 \pm 0.25^{\mathrm{a}}$ & $9.31 \pm 0.39^{\mathrm{a}}$ & $0.82 \pm 0.08^{\mathrm{b}}$ & $1.15 \pm 0.00^{\mathrm{a}}$ \\
N4 & $10.15 \pm 0.04^{\mathrm{b}}$ & $8.65 \pm 0.23^{\mathrm{ab}}$ & $0.92 \pm 0.14^{\mathrm{b}}$ & $1.22 \pm 0.16^{\mathrm{a}}$ \\
N5 & $12.25 \pm 0.20^{\mathrm{a}}$ & $8.28 \pm 0.31^{\mathrm{b}}$ & $0.55 \pm 0.06^{\mathrm{c}}$ & $1.10 \pm 0.10^{\mathrm{a}}$ \\
\hline
\end{tabular}

\footnotetext{
${ }^{1)} \mathrm{N} 1$, whited rice flour 'Nuruk' made with $A$. oryzae; N2, pigmented rice flour 'Nuruk' made with $A$. oryzae; N3, pigmented rice flour 'Nuruk' made with $A$. kawachii; N4, pigmented rice flour 'Nuruk' made with A. niger; N5, pigmented rice flour 'Nuruk' made with $P$. candidum. ${ }^{2)}$ All values are mean \pm SD.
}

${ }^{3)}$ Values with different superscript letters in the same column are significantly different at $\mathrm{p}<0.05$ by Duncan's multiple range test $(\mathrm{a}>\mathrm{b}>\mathrm{c}>\mathrm{d})$. 


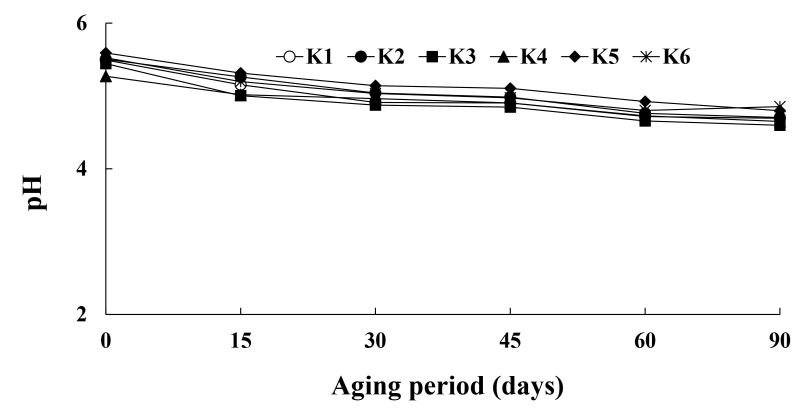

Fig. 3. Changes in pH of 'Kochujang' made with pigmented rice flour 'Nuruk' during aging.

K1, 'Kochujang' made with N1; K2, 'Kochujang' made with N2; K3, 'Kochujang' made with N3; K4, 'Kochujang' made with N4; K5, 'Kochujang' made with N5; K6, 'Kochujang' made with N2+N3+ $\mathrm{N} 4+\mathrm{N} 5$.

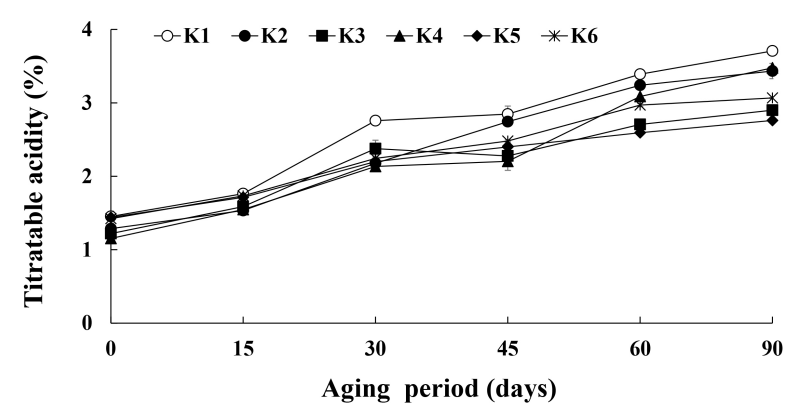

Fig. 4. Changes in titratable acidity of 'Kochujang' made with pigmented rice flour 'Nuruk' during aging.

K1, 'Kochujang' made with N1; K2, 'Kochujang' made with N2; K3, 'Kochujang' made with N3; K4, 'Kochujang' made with N4; K5, 'Kochujang' made with N5; K6, 'Kochujang' made with N2+N3+ N4+N5.

균값이 4.59-4.79이었다고 보고하여 본 연구에서 숙성한 고 추장도 비슷한 범위 내에 포함되었다. 고추장의 적정 산도를 측정한 결과는 Fig. 4에서 보는 바와 같이 숙성 기간이 경과 됨에 따라 지속적으로 상승하는 경향을 보였다. 담금 초기 고 추장의 적정 산도는 $1.15-1.45 \%$ 였고, 숙성 90 일째의 적정산 도는 2.76-3.71\%로 약 $1.32-2.56 \%$ 가량 증가하였다. 시료구 별 적정산도 값은 숙성 90 일째 $\mathrm{N} 1$ 누룩을 함유한 고추장이 $3.71 \%$ 로 가장 높게 나타났다. 앞서 누룩의 품질 평가에서 산 도 값이 가장 높아서 고추장의 적정 산도 값에 영향을 줄 것 으로 판단한 N4 누룩을 첨가해 제조한 고추장은 $3.48 \%$ 로 약 간 높았지만 다른 시료구의 값들에 비해 크게 범위를 벗어나 지 않았다. 고추장은 숙성이 되면서 미생물의 왕성한 증식에 의한 발효 과정으로 $\mathrm{pH}$ 는 저하되고 산도는 증가시킨다 $(\mathrm{Kim}$ 등, 1993). 본 연구에서도 모든 시료구가 동일한 경향을 보여
정상적으로 발효 숙성이 진행되었다고 판단된다.

\section{고추장의 수분 함량}

숙성 중인 고추장의 수분 함량 변화를 측정한 결과는 Fig. 5 와 같다. 일반적으로 발효 및 숙성 과정에서의 수분 함량은 상승하는 것으로 알려져 있으며, 이는 발효의 기질이 되는 당 류 성분이 가수분해될 때 최종 분해 산물로 $\mathrm{H}_{2} \mathrm{O}$ 를 생성하기 때문이다(Cha와 Kim, 1997). 백미 및 유색미 쌀가루 개량누 룩을 첨가한 고추장의 숙성 기간에 따른 수분 함량을 조사한 결과, 담금 초기의 수분 함량은 45.70-47.47\%였고, 숙성 90 일째는 담금 초기보다 수분 함량이 약 2-6\%씩 증가해 50.10$52.10 \%$ 의 함량을 보였으며, 시료구별 수분함량 차이는 크지 않았다. 이와 관련해서 $\mathrm{Kim}$ 등(2012a)이 보고한 쌀누룩의 혼 합비율을 달리한 고추장의 수분함량 변화에서 숙성 중에 수 분함량이 증가하였고, 최종 수분 함량 또한 $44 \%$ 내외였다고 보고해 본 연구와 유사하였다.

\section{고추장의 환원당 함량}

고추장에 있어서 단맛은 glucose, maltose 등의 당류로부 터 영향을 받으며 이러한 당류의 함량을 측정하는데 있어서 주로 환원당 함량을 측정하는 것은 고추장의 발효 정도와 품 질을 파악하는데 중요한 지표이다(Cha 와 Kim, 1997). 4종의 곰팡이 균주와 쌀 품종에 따른 고추장의 환원당 함량 변화를 측정한 결과는 Fig. 6 와 같다. 담금 초기( 0 일 차)의 환원당 함 량은 $\mathrm{N} 1$ 누룩을 첨가한 고추장이 $8.77 \%$ 로 가장 낮은 함량을 보였고, 유색미를 활용해 제조된 N2, N3, N4, N5 누룩 및 $\mathrm{N} 2+\mathrm{N} 3+\mathrm{N} 4+\mathrm{N} 5$ 혼합 누룩을 첨가해 제조한 5 종의 고추장은 $12.82 \%, 13.31 \%, 14.59 \%, 14.05 \%$ 및 $14.45 \%$ 로 백미 누룩인 $\mathrm{N} 1$ 누룩을 첨가한 고추장보다 모두 높게 나타났다. 이러한

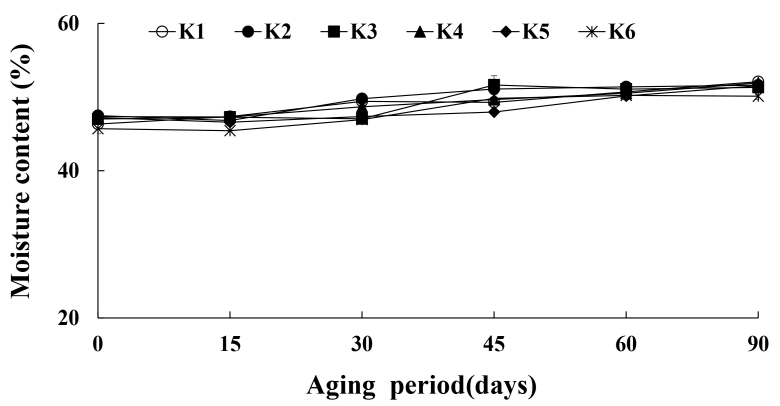

Fig. 5. Changes in moisture content of 'Kochujang' made with pigmented rice flour 'Nuruk' during aging.

K1, 'Kochujang' made with N1; K2, 'Kochujang' made with N2; K3, 'Kochujang' made with N3; K4, 'Kochujang' made with N4; K5, 'Kochujang' made with N5; K6, 'Kochujang' made with N2+N3+ $\mathrm{N} 4+\mathrm{N} 5$. 


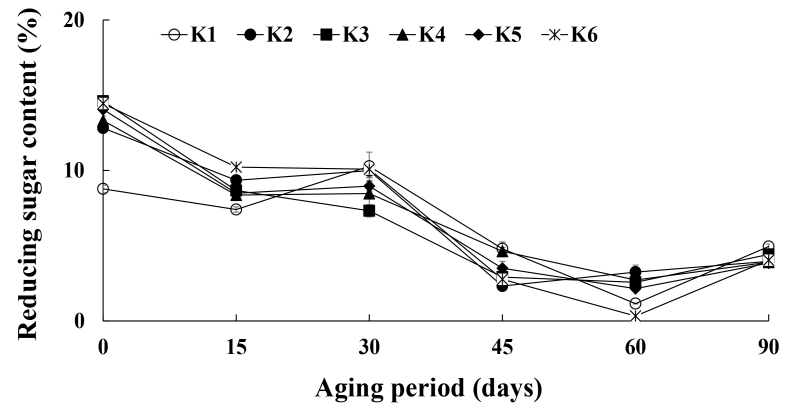

Fig. 6. Changes in reducing sugar content of 'Kochujang' made with pigmented rice flour 'Nuruk' during aging.

K1, 'Kochujang' made with N1; K2, 'Kochujang' made with N2; K3, 'Kochujang' made with N3; K4, 'Kochujang' made with N4; K5, 'Kochujang' made with N5; K6, 'Kochujang' made with N2+N3+N4+N5.

담금 초기의 환원당 함량 차이는 백미 누룩과 유색미 누룩의 쌀 품종에 따라 전분의 당화력 차이가 있는 것으로 판단된다. 이후 숙성 90 일째의 백미 누룩과 유색미 누룩 첨가 고추장의 환원당 함량은 유의적 차이를 보이지 않았다. 숙성 기간에 따 른 고추장의 환원당 함량은 시료구별 약간의 차이는 있었으 나 숙성 45일-60일째까지 감소하였고, 이후 함량을 유지하거 나 약간 증가하는 경향을 보였다. 이러한 결과는 $\mathrm{Kim}$ 등 (2012b)이 보고한 더덕분말을 첨가한 고추장의 환원당 함량 변화에서도 숙성 6 주째까지 환원당 함량이 감소하는 경향을 보이다가 이후 약간 증가했다고 보고해 본 연구의 환원당 함 량 변화 패턴과 비슷한 결과를 보였다.

\section{고추장의 식염 함량}

고추장에 포함된 식염 성분은 제품의 맛과 보존성에서 영 향을 준다(Choi 등, 2000). 숙성 과정 중 고추장의 식염 함량 을 측정한 결과는 Fig. 7과 같다. 숙성 기간에 따른 식염 함량 은 담금 초기에서 숙성 45 일째까지는 약 $0.3-0.7 \%$ 정도 함량 이 줄어드는 경향을 보였으나, 45 일-60일째 사이에 약간 증 가하였으며, 60 일째 이후에 다시 감소하여 숙성 초기의 함량 과 비슷한 함량을 보였다. 식염 함량의 변화 패턴을 살펴보면 45일-60일째 사이에 식염 함량이 약간 증가하는 경향을 보였 다. 이러한 이유는 수분 함량 변화 측정 결과에서 보면 숙성 45 일-60일째 수분 함량이 약간 감소하는 경향을 보였다. 따 라서 수분 함량이 줄어들면서 중량 대비 식염 함량이 높아졌 을 것으로 판단된다. 고추장 시료구별 식염 함량 차이는 유의 적 차이가 없었으며, 고추장 제조시에 첨가되었던 식염의 함 량이 유지되었다.

\section{고추장의 색도}

고추장의 품질을 측정할 때 중요 요소 중 하나인 색도를

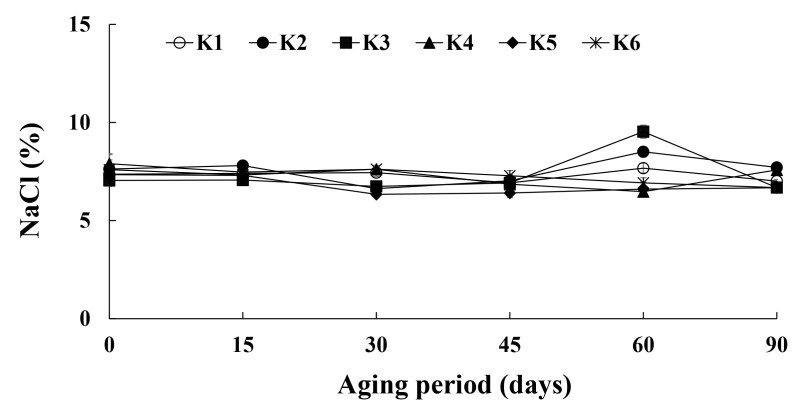

Fig. 7. Changes in salinity of 'Kochujang' made with pigmented rice flour 'Nuruk' during aging.

K1, 'Kochujang' made with N1; K2, 'Kochujang' made with N2; K3, 'Kochujang' made with N3; K4, 'Kochujang' made with N4; K5, 'Kochujang' made with N5; K6, 'Kochujang' made with N2+N3+N4+N5.

측정한 결과는 Fig. 8 에 나타내었다. 숙성 기간 및 쌀 품종에 따른 고추장의 색도를 측정한 결과, 제조 직후의 색도는 백미 누룩을 첨가해 제조한 고추장이 유색미 누룩을 첨가해 제조 한 고추장보다 $\mathrm{L}, \mathrm{a}$ 및 $\mathrm{b}$ 값이 모두 전반적으로 높게 나타났 다. 숙성 90 일째 색도는 $\mathrm{L}$ 및 a값의 경우, 담금 초기의 값과 같이 백미 누룩을 첨가해 제조한 고추장이 유색미 누룩으로 제조한 고추장 시료군보다 높은 값을 보였고, $\mathrm{b}$ 값의 경우에 는 유의적 차이가 없었다. 본 연구 설계시 유색미의 육안으로 보이는 붉은빛 색깔에 의해 유색미 누룩을 첨가해 제조한 고 추장의 $\mathrm{a}$ 값이 백미 누룩을 첨가해 제조한 고추장보다 값이 높을 것으로 예상했으나, 백미 누룩을 첨가해 제조한 고추장 이 높게 나타났다. 이러한 결과값에 대한 이유를 분석해 볼 때 적색의 선명도에서 백미 누룩을 첨가해 제조한 고추장의 경우 명도를 나타내는 L값이 높아 고춧가루 적색의 선명도가 높아져 a값이 높았고, 유색미 누룩을 첨가해 제조한 고추장 의 a값은 유색미가 가지는 흑자색에서 기인된 어두운색이 적 색의 선명도를 떨어뜨려 오히려 a값이 낮게 나타난 결과라고 판단된다. 숙성 경과에 따른 색도의 변화는 담금 초기에는 $\mathrm{L}$, $\mathrm{a}$ 및 $\mathrm{b}$ 값이 모두 감소하는 경향을 보였다. 이는 고추장 제조 시 첨가된 전분질 성분 등이 담금 초기에 활발한 대사를 거치 는 과정에서 발효 대사와 Maillard 반응 등에 의한 산화에 의 해 값이 감소하는 것으로 판단된다(Lee와 Lee, 2006).

\section{고추장의 관능적 품질}

백미와 유색미 쌀가루 개량누룩을 첨가해 제조한 6 종의 고 추장 관능평과 결과는 Table 4에서 보는 바와 같다. 시료구별 관능평가 결과, 모두 평가 항목(색, 향, 단맛, 짠맛, 매운맛, 감 칠맛 및 종합 기호도)에서 A. oryzae 균주 유색미 쌀가루 개 량누룩(N2 누룩)을 첨가해 제조한 고추장의 기호도가 가장 높게 나타났다. 색의 기호도를 보면 앞서 색도측정 결과, 적 색도를 나타내는 a값이 A. oryzae 균주 백미 쌀가루 개량누룩 

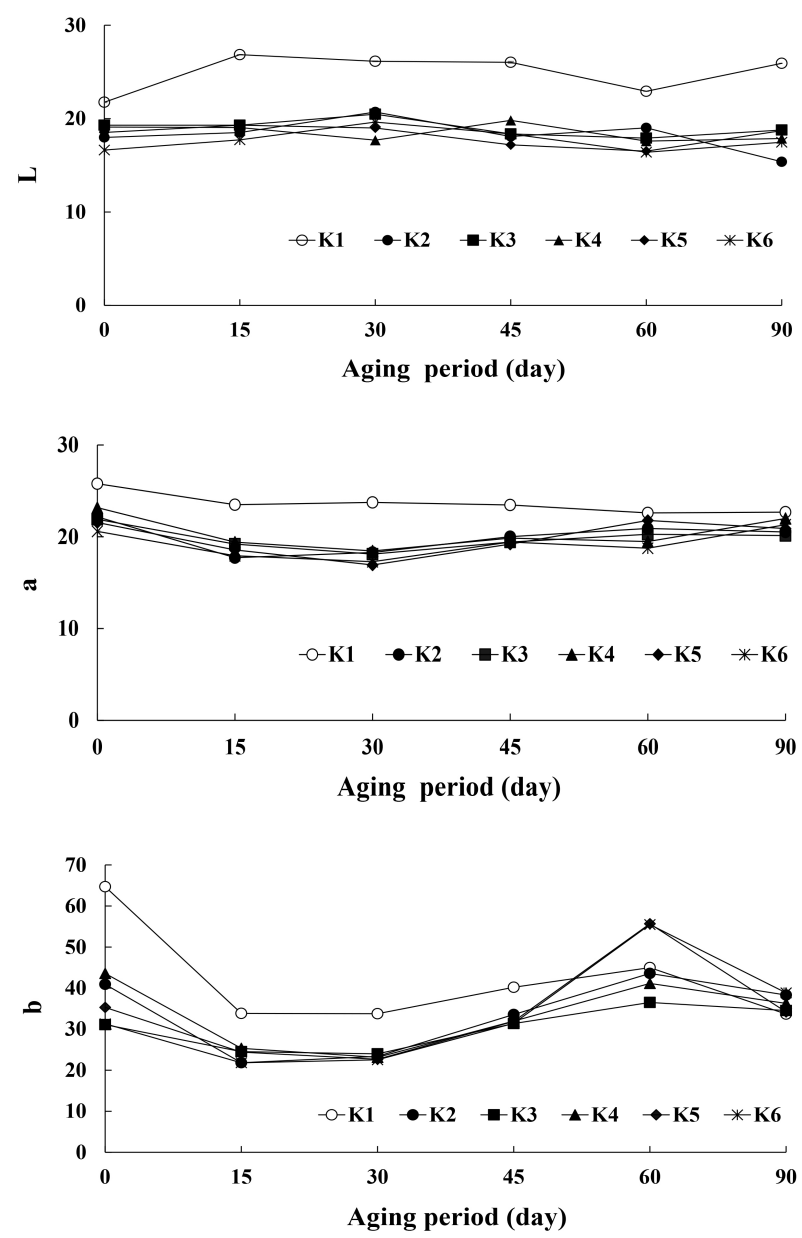

Fig. 8. Changes in color values of 'Kochujang' made with pigmented rice flour 'Nuruk' during aging.

$\mathrm{K} 1$, 'Kochujang' made with N1; K2, 'Kochujang' made with N2; K3, 'Kochujang' made with N3; K4, 'Kochujang' made with N4; K5, 'Kochujang' made with N5; K6, 'Kochujang' made with N2+N3+ $\mathrm{N} 4+\mathrm{N} 5$.
(N1 누룩)을 첨가해 제조한 고추장이 유색미 누룩을 첨가해 제조한 고추장 시료군보다 높게 나타났다. 하지만 관능평가 결과에서 색의 기호도는 N2 누룩으로 제조한 고추장의 기호 도가 높았다. 이러한 결과는 기계적으로 측정되는 색도의 값 과 사람의 육안으로 주관적으로 평가되는 색의 기호도가 차 이가 있다는 것을 의미한다. 곰팡이 균주별 누룩 첨가에 따른 고추장의 관능평가 결과를 보면 A. oryzae 균주로 제조된 백 미와 유색미 누룩(N1, N2 누룩)첨가 고추장이 A. kawachii, A. niger 및 P. candidum 균주로 제조된 유색미 누룩(N3, N4, $\mathrm{N} 5$ 누룩 및 $\mathrm{N} 2+\mathrm{N} 3+\mathrm{N} 4+\mathrm{N} 5$ 혼합 누룩) 첨가 고추장보다 전 반적으로 기호도가 높게 나타났다. 따라서 향후 고추장 제조 에 있어 A. oryzae 균주 유색미 누룩으로 제조되는 고추장은 활용 가치가 있을 것으로 판단된다.

\section{요 약}

본 연구에서는 우리나라 전통 고추장의 품질 향상의 일환 으로 유색미를 활용해 곰팡이 균주별 쌀가루 개량누룩을 제 조하고, 그 누룩들을 활용해 숙성 중에 고추장의 품질 특성 변화를 확인하였다. 제조된 누룩의 $\mathrm{pH}$ 와 산도를 측정한 결과, $\mathrm{pH}$ 는 A. oryzae 균주를 첨가해 제조한 유색미 쌀가루 개량누 룩(N2 누룩)이 5.83으로 가장 높았고, 산도의 경우 A. niger 균주를 첨가해 제조한 유색미 쌀가루 개량누룩(N4 누룩)이 2.69로 가장 높았다. 누룩의 일반성분 측정 결과, 조회분 함 량이 유색미를 이용해 제조한 누룩이 1.10-1.14\%로, 백미를 이용해 제조한 누룩의 $0.42 \%$ 보다 높게 나타났다. 제조된 쌀 가루 개량누룩 첨가 고추장의 숙성 기간에 따른 $\mathrm{pH}$ 의 변화는 감소하는 경향을 보였고, 적정산도는 숙성 기간이 경과됨에 따라 지속적으로 상승하는 경향을 보였다. 숙성 과정에서의 수분 함량은 약 2-6\%씩 증가했고, 시료구별 수분함량 차이는

Table 4. Sensory test of 'Kochujang' made with pigmented rice flour 'Nuruk'

\begin{tabular}{|c|c|c|c|c|c|c|c|c|}
\hline Sample ${ }^{1)}$ & Color & Flavor & Sweetness & Salty & Spicy & $\begin{array}{l}\text { Delicate } \\
\text { flavor }\end{array}$ & $\begin{array}{l}\text { Savory } \\
\text { taste }\end{array}$ & $\begin{array}{c}\text { Overall } \\
\text { preference }\end{array}$ \\
\hline $\mathrm{K} 1$ & $5.90 \pm 1.45^{2) \mathrm{ab} 3)}$ & $5.70 \pm 1.16^{\mathrm{ab}}$ & $4.60 \pm 0.97^{\mathrm{b}}$ & $5.00 \pm 0.94^{\mathrm{ab}}$ & $4.70 \pm 0.95^{\mathrm{b}}$ & $4.90 \pm 1.29^{\mathrm{b}}$ & $5.00 \pm 1.15^{\mathrm{b}}$ & $5.40 \pm 0.97^{\mathrm{b}}$ \\
\hline $\mathrm{K} 2$ & $6.80 \pm 1.32^{\mathrm{a}}$ & $6.60 \pm 1.26^{\mathrm{a}}$ & $5.60 \pm 1.26^{\mathrm{a}}$ & $5.80 \pm 1.03^{\mathrm{a}}$ & $6.00 \pm 0.82^{\mathrm{a}}$ & $6.40 \pm 1.26^{\mathrm{a}}$ & $6.30 \pm 1.16^{\mathrm{a}}$ & $7.00 \pm 0.67^{\mathrm{a}}$ \\
\hline $\mathrm{K} 3$ & $5.60 \pm 0.84^{\mathrm{ab}}$ & $5.50 \pm 1.08^{\mathrm{abc}}$ & $4.30 \pm 0.95^{\mathrm{b}}$ & $3.90 \pm 1.45^{\mathrm{b}}$ & $4.60 \pm 1.07^{b}$ & $4.60 \pm 1.07^{\mathrm{b}}$ & $5.00 \pm 1.70^{\mathrm{b}}$ & $4.80 \pm 1.40^{\mathrm{bc}}$ \\
\hline K4 & $5.50 \pm 1.27^{\mathrm{b}}$ & $5.00 \pm 1.05^{\mathrm{bc}}$ & $4.30 \pm 1.06^{\mathrm{b}}$ & $4.50 \pm 1.18^{\mathrm{b}}$ & $4.40 \pm 0.97^{b}$ & $4.60 \pm 1.07^{\mathrm{b}}$ & $4.70 \pm 0.67^{\mathrm{b}}$ & $4.70 \pm 1.06^{\mathrm{bc}}$ \\
\hline K5 & $5.50 \pm 1.27^{\mathrm{b}}$ & $4.90 \pm 1.10^{\mathrm{bc}}$ & $3.90 \pm 0.57^{\mathrm{b}}$ & $4.00 \pm 1.25^{\mathrm{b}}$ & $4.70 \pm 0.95^{\mathrm{b}}$ & $4.40 \pm 0.70^{\mathrm{b}}$ & $4.50 \pm 0.53^{\mathrm{b}}$ & $4.40 \pm 0.70^{\mathrm{c}}$ \\
\hline K6 & $5.50 \pm 1.43^{\mathrm{b}}$ & $4.40 \pm 1.43^{\mathrm{c}}$ & $4.40 \pm 1.58^{\mathrm{b}}$ & $4.10 \pm 1.37^{b}$ & $4.50 \pm 1.08^{b}$ & $4.20 \pm 1.03^{\mathrm{b}}$ & $4.50 \pm 1.08^{\mathrm{b}}$ & $4.30 \pm 1.06^{\mathrm{c}}$ \\
\hline
\end{tabular}

${ }^{1)}$ K1, 'Kochujang' made with N1; K2, 'Kochujang' made with N2; K3, 'Kochujang' made with N3; K4, 'Kochujang' made with N4; K5, 'Kochujang' made with N5; K6, 'Kochujang' made with $\mathrm{N} 2+\mathrm{N} 3+\mathrm{N} 4+\mathrm{N} 5$.

${ }^{2)}$ All values are mean \pm SD.

${ }^{3)}$ Values with different superscript letters in the same column are significantly different at $\mathrm{p}<0.05$ by Duncan's multiple range test ( $\mathrm{a}>\mathrm{b}>\mathrm{c}$ ). 
크지 않았다. 숙성 기간에 따른 고추장의 환원당 함량은 시료 구별 약간의 차이는 있었으나 숙성 45일-60일째까지 감소하 였고, 이후 함량을 유지하거나 약간 증가하는 경향을 보였다. 식염 함량의 변화는 45 일-60일째 사이에 식염 함량이 약간 증가하는 경향을 보였고, 시료구별 식염 함량은 유의적 차이 가 없었다. 색도는 백미 누룩을 첨가해 제조한 고추장이 유색 미 누룩을 첨가해 제조한 고추장보다 $\mathrm{L}, \mathrm{a}$ 및 $\mathrm{b}$ 값이 모두 전 반적으로 높게 나타났다. 고추장 시료구별 관능평가 결과, 모 두 평가 항목(색, 향, 단맛, 짠맛, 매운맛, 감칠맛 및 종합 기호 도)에서 $\mathrm{N} 2$ 누룩을 첨가해 제조한 고추장의 기호도가 가장 높 게 나타났다. 따라서 향후 고추장 제조에 있어 A. oryzae 균주 유색미 누룩(N2 누룩)으로 제조되는 고추장은 활용 가치가 있을 것으로 판단된다.

\section{감사의 글}

본 연구는 농촌진흥청 산학연협력 광역화사업(2019-0172) 전남농업기술원 쌀산학연협력단의 연구비 지원을 받아 실행 한 결과의 일부로 이에 감사드립니다.

\section{Conflict of interests}

The authors declare no potential conflict of interest.

\section{ORCID}

Hee Won Lee https://orcid.org/0000-0002-5675-2581

Chang Ki Huh https://orcid.org/0000-0003-4456-8477

\section{References}

AOAC. Official Methods of Analysis. 15th ed, Association of Official Analytical Chemists, Washington DC, USA, 5 (1990)

Cha EJ, Kim KJ. Study on the preparation of the saccharification Kochujang with retrogradated starch food and changes in physiochemical properties during the aging. J Korean Diet Assos, tetic Association, 3, 23-29 (1997)

Cha MN, Yoon Y, Jang SA, Song GS, Kim YS. Quality characteristic of saccharified materials manufactured from germinated barley. Korean J Food Sci Technol, 43, 315-320 (2011)

Choi JY, Lee TS, Noh BS. Quality characteristic of the Kochujang prepared with mixture of Meju and Koji during fermentation. Korean J Food Sci Technol, 32,
125-131 (2000)

Han EH, Lee TS, Noh BS, Lee DS. Quality characteristics in mash of Takju prepared by using different Nuruk during fermentation. Korean J Food Sci Technol, 29, 555-562 (1997)

Hatanaka C, Kobara Y. Determination of glucose by a modification of Somogyi-Nelson method. Agric Biol Chem, 44, 2943-2949 (1980)

Huh CK. Effect of recipe for chestnut wine on fermentation and quality characteristics. MS Thesis, Sunchon National University, Korea, p 50 (2006)

Jin HS, Kim JB, Lee KJ. Major microbial composition and its correlation to the taste of Sunchang traditional Kochujang. Korean J Food Nutr, 20, 363-368 (2007)

Kim OK, Sung JM, Ryu HS. Antioxidative activity and quality characteristics of Kochujang amended with different ratios of Deodeok (Condonopsis lanceolata) root powder. J East Asian Soc Dietary Life, 22, 667-676 (2012b)

Kim YS, Shin DB, Jeong MC, Oh HI, Kang TS. Changes in quality characteristics of traditional Kochujang during fermentation. Korean J Food Sci Technol, 25, 724-729 (1993)

Kim YJ, Byun MH. Why home meal replacement has been developed?. Food Industry and Nutrition, 22, 8-12 (2017)

Kim YJ, Choi YH, Park SY, Choi HS, Jeong ST, Kim EM. Quality of Kochujang with different ratios of Rice-Nu ruk. Korean J Community Living Sci, 23, 339-346 (2012a)

Kwon YH, Lee AR, Kim HR, Kim JH, Ahn BH. Quality properties of Makgeolli brewed with various rice and Koji. Korean J Food Sci Technol, 45, $70-76$ (2013)

Lee CG, Na JH, Park SJ, Jeong JH, Kim CM, Kim BS, Han HB, Huh CK. Quality analysis of Makgeolli made with non-steamed rice flour Nuruk by various fungal strains. Korean J Food Preserv, 26, 496-504 (2019)

Lee HH, Lee JH, Ko YJ, Park MH, Lee JO, Ryu CH. Changes in allergenicity and quality of Nuruk during fermentation. J Korean Soc Food Sci Nutr, 38, 1, 7682 (2009)

Lee MJ, Lee JH. Quality characteristics of Kochujang prepared with Maesil (Prunus mume) extract during aging. J Korean Soc Food Sci Nutr, 35, 622-628 (2006) 
Lee S, Yoo SM, Park BR, Han HM, Kim HY. Analysis of quality state for Gochujang produced by regional rural families. J Korean Soc Food Sci Nutr, 43, 1088-1094 (2014)

Oh JY, Kim YS, Shin DH. Changes in physicochemical characteristics of low-salted Kochujang with natural preservatives during fermentation. Korean J Food Sci Technol, 34, 835-841 (2002)

Oh YS, Baek JW, Park KY, Hwang JH, Lim SB. Physicochemical and functional properties of Kochujang with broccoli leaf powder. J Korean Soc Food Sci Nutr, 42, 675-681 (2013)

Park BH, Jeon ER, Kim SD, Cho HS. Cooking quality characteristics of cooked rice of YenipSambab with pigmented rice. Korean J Food Preserv, 19, 185-192
(2012)

Park ES, Heo JH, Ju JH, Park KY. Changes in quality characteristics of Gochujang prepared with different ingredients and Meju starters. J Korean Soc Food Sci Nutr, 45, 880-888 (2016a)

Park JY, Ham H, Han SI, Oh SH, Song YC, Cho JH, Hur YJ, Lee YY, Lee BW, Choi YH. Comparison of antioxidant components and antioxidant activities of colored rice varieties (Oryza sativa L.) cultivated in southern plain. J Korean Soc Food Sci Nutr, 45, 1214-1220 (2016b)

Park MK, Lee JM, Park CH. Comparisons on the quality characteristics of pigmented rice CholPyon with those of brown and white rice. Korean J Soc Food Cookery Sci, 18, 471-475 (2002) 